\title{
Iron absorption from fortified flat breads
}

\author{
BY MOHAMED EL GUINDI, SEAN R. LYNCH AND JAMES D. COOK* \\ Department of Medicine, University of Kansas Medical Center, Kansas City, \\ Kansas 66103, USA
}

(Received 1 July 1987 - Accepted 6 October 1987)

\begin{abstract}
1. Radio-iron absorption measurements were performed in healthy volunteer subjects to assess the availability of fortification Fe added to various bread products.

2. When ferrous sulphate was used as a fortifier, Fe absorption from a traditional Egyptian flat bread (Baladi) averaged only $16 \%$ of that observed with European bread. This difference was attributed to the high extraction flour used to prepare Baladi bread.

3. The inhibiting effect of Baladi bread was largely eliminated by adding EDTA to the flour before baking.
\end{abstract}

Wheat flour is the only food vehicle that has been used extensively for iron fortification at a national level. At the present time, fortification $\mathrm{Fe}$ in wheat flour and bakery products provides approximately $20 \%$ of the Fe consumed in North America and nearly $40 \%$ of that in Sweden. Although epidemiological surveys have never fully defined the efficacy of wheatflour fortification, it is commonly assumed that it has contributed to the reduction in the prevalence of $\mathrm{Fe}$ deficiency in countries where food $\mathrm{Fe}$ fortification is mandatory (Hallberg et al. 1979; Cook et al. 1986).

A major advantage of employing bread products as a vehicle for $\mathrm{Fe}$ is the facilitating effect of wheat flour on $\mathrm{Fe}$ absorption as compared with other cereal foods. Fe absorption from Western wheat-based meals in Fe-deficient subjects varies between 20 and $30 \%$, while only $2-4 \%$ of the $\mathrm{Fe}$ in rice and maize meals is assimilated (Cook et al. 1972; BjornRasmussen \& Hallberg, 1974; Hallberg et al. 1977; International Nutritional Anemia Consultative Group (INACG), 1982). Because wheat is a dietary staple in Egypt where Fe deficiency is highly prevalent, the fortification of wheat bread is a logical intervention strategy in this country. However, there is reason to suspect that Egyptian flat breads (Baladi and Shami) differ in their effect on $\mathrm{Fe}$ availability compared with European bread consumed in countries where there is national fortification. Baladi bread is made with $82 \%$ extraction flour produced within the country, whereas Shami bread is prepared with imported $72 \%$-extraction flour. Absorption studies in humans indicate that higherextraction flour substantially reduces the availability of added $\mathrm{Fe}$ (Widdowson \& McCance, 1942; Bjorn-Rasmussen, 1974; Simpson et al. 1981). Furthermore, both types of Egyptian breads are baked at a much higher temperature than European bread. The present report describes studies performed to measure the availability of fortification $\mathrm{Fe}$ in commonly consumed Egyptian breads.

\section{MATERIALS AND METHODS \\ Study design}

Four separate studies were performed in groups of eight to eleven volunteer subjects. In each study, four $\mathrm{Fe}$ absorption tests were carried out as two successive sets of doubleradioisotope measurements. Study 1 was performed to determine the validity of extrinsic radio-Fe labelling for evaluating the availability of $\mathrm{Fe}$ in Egyptian breads. Study 2 
compared absorption from different types of bread eaten alone and study 3 examined the absorption of fortified flat breads consumed with typical Egyptian meals. Because absorption was poor in the first three studies, study 4 was performed to determine whether absorption from fortified Egyptian bread could be improved by adding EDTA to the fortifier, ferrous sulphate.

\section{Subjects}

A total of thirty-six volunteers, fifteen male and twenty-one female, between the ages of 19 and 35 years participated in these studies. Six were Fe-deficient as defined by a serum ferritin level less than $12 \mu \mathrm{g} / \mathrm{l}$. None gave a history of disorders that might affect the absorption of $\mathrm{Fe}$ from the gastrointestinal tract and all stated that they were in good health. Written informed consent was obtained from each subject before entering the study and all experimental procedures were approved by the Human Subjects Committee at the University of Kansas Medical Center.

\section{Absorption measurements}

All test meals were eaten between 07.00 and 09.00 hours after a $10 \mathrm{~h}$ fast. Only water was allowed for $3 \mathrm{~h}$ following the meals. Each meal was labelled with either $1 \mu \mathrm{Ci}{ }^{59} \mathrm{FeCl}_{3}$ or $3 \mu \mathrm{Ci}^{55} \mathrm{FeCl}_{3}$, except in study 1 in which both tags were used in the first meal. On the $1 \mathrm{st}$ day of each study, $15 \mathrm{ml}$ blood were drawn for measurements of serum ferritin (Miles et al. 1974) and background blood radioactivity. Test meals were administered on days 2 and 3. After $14 \mathrm{~d}, 25 \mathrm{ml}$ blood were obtained to measure incorporated erythrocyte radioactivity, and the second pair of test meals was administered on the subsequent $2 \mathrm{~d}$. Study 1 comprised only two test meals given on days 2 and 16 . A further $25 \mathrm{ml}$ blood were drawn $14 \mathrm{~d}$ after the final meal. Absorption from the second pair of meals was calculated from the increase in blood radioactivity between days 17 and 30 . Assays for ${ }^{55} \mathrm{Fe}$ and ${ }^{59} \mathrm{Fe}$ were performed on duplicate $10 \mathrm{ml}$ blood samples using a modification of the method of Eakins and Brown (Bothwell et al. 1979). Sufficient counts were obtained on each sample to reduce the net counting error for each isotope to less than $\pm 2 \%$ in subjects absorbing more than $1 \%$ of the test dose. Absorption was determined on the basis of the blood volume (Wennesland et al. 1959; Brown et al. 1962) assuming 80\% erythrocyte incorporation (Hosain et al. 1967) of absorbed radio-Fe.

\section{Test meals}

For studies 1 and 2 each serving of Baladi bread was prepared by thoroughly mixing $100 \mathrm{~g} 82 \%$-extraction stone-milled Egyptian flour with $65 \mathrm{ml}$ water, $0.5 \mathrm{~g}$ salt and $1.5 \mathrm{~g}$ yeast. The dough was allowed to rise for $2 \mathrm{~h}$. Each portion was then rolled into a disk approximately $180 \mathrm{~mm}$ in diameter and allowed to rise for an additional $1 \mathrm{~h}$. The loaves were baked for $1 \mathrm{~min}$ at $470^{\circ}$ in a muffle furnace. The loaf size was reduced by $25 \%$ in studies 3 and 4 . Shami bread was prepared from $72 \%$-extraction flour in the same way. The identical recipe and $72 \%$-extraction flour were also used to make French bread, but the dough was made into rolls and baked at $250^{\circ}$ for $5 \mathrm{~min}$. The $\mathrm{Fe}$ contents of flour samples and portions of homogenized meals were determined by atomic absorption spectroscopy after they had been dry ashed.

The validity of the extrinsic-tag technique was examined in study 1 . The first meal contained only a loaf of unfortified Baladi bread served with $14 \mathrm{~g}$ butter. Loaves were prepared individually to assure that the Egyptian flour was mixed with wheat that had been biosynthetically labelled with ${ }^{55} \mathrm{Fe}$ by hydroponic culture (Moore \& Dubach, 1951); $1 \mathrm{~g}$ ${ }^{55} \mathrm{Fe}$-labelled flour (Fe content $12 \mathrm{mg} / \mathrm{kg}$, specific activity $0.25 \mu \mathrm{Ci} / \mu \mathrm{g}$ ) was carefully mixed into the dough of each loaf to provide $3 \mu \mathrm{Ci}{ }^{55} \mathrm{Fe}$ per loaf. An extrinsic tag containing $1 \mu \mathrm{Ci}{ }^{59} \mathrm{Fe}$ as $\mathrm{FeCl}_{3}(0 \cdot 1 \mathrm{mg} \mathrm{Fe})$ in $1.0 \mathrm{ml} 0.01 \mathrm{M}$-hydrochloric acid was also mixed into the 
dough. Thus an accurately measured quantity of each radio-Fe tracer was administered to each volunteer subject. The second meal in study 1 was designed to test the effect of baking on radio-Fe absorption. Only extrinsic tags were used. Sufficient $\mathrm{FeSO}_{4}$ (Paniplus Co., Olathe, KS) was added to the flour to provide $2.2 \mathrm{mg}$ additional Fe per loaf, increasing the total $\mathrm{Fe}$ content to $4.2 \mathrm{mg}$. The radio-Fe tag $\left(3 \mu \mathrm{Ci}{ }^{55} \mathrm{Fe}\right.$ as $\mathrm{FeSO}_{4}$ with $0.1 \mathrm{mg}$ carrier $\mathrm{Fe}$ in $0.01 \mathrm{M}$-sulphuric acid) was mixed into the dough for each loaf before baking. The second extrinsic tag $\left(0 \cdot 1 \mathrm{mg} \mathrm{Fe}\right.$ as $\mathrm{FeCl}_{3}$ in $1 \mathrm{ml} 0.01 \mathrm{M}-\mathrm{HCl}$ containing $1 \mu \mathrm{Ci}^{50} \mathrm{Fe}$ ) was injected into the interior surface of the bread just before it was eaten.

The availability of $\mathrm{Fe}$ in various breads was examined in study 2 in which four test meals were given on separate days. The first three meals $(\mathrm{A}-\mathrm{C})$ consisted of a $120 \mathrm{~g}$ loaf of Baladi, Shami, or French bread with $14 \mathrm{~g}$ butter. Fortification $\mathrm{Fe}\left(3 \mathrm{mg} \mathrm{Fe}\right.$ as $\mathrm{FeSO}_{4}$ was added to the $100 \mathrm{~g}$ flour used to prepare each loaf. The extrinsic tag $(0.1 \mathrm{mg} F$ $\mathrm{FeSO}_{4}$ in $1.0 \mathrm{ml} 0.01 \mathrm{M}-\mathrm{H}_{2} \mathrm{SO}_{4}$ ) was injected into each loaf just before serving. Meal $\mathrm{D}$ was the reference dose, i.e. a freshly prepared solution of $3 \mathrm{mg} \mathrm{Fe}$ as $\mathrm{FeSO}_{4}$ and $18.9 \mathrm{mg}$ ascorbic acid (molar ratio, $2: 1$ ) in $50 \mathrm{ml}$ water.

$\mathrm{Fe}$ absorption from fortified Baladi bread consumed with Egyptian meals was evaluated in study 3. Meals A and B, representing a typical lunch or dinner meal, contained $125 \mathrm{~g}$ green beans (Phaseolus vulgaris), $17 \mathrm{~g}$ minced onion, $2.8 \mathrm{~g}$ margarine and $18 \mathrm{~g}$ tomato paste cooked in $40 \mathrm{ml}$ water. They were served with $100 \mathrm{~g}$ boiled rice and an Fe-fortified Baladi bread loaf. The total Fe content of each meal was $5.5 \mathrm{mg}$. Water was given ad lib. with meal $\mathrm{A}$ and $180 \mathrm{ml}$ hot tea with meal B. Meal C was similar to an Egyptian breakfast and comprised $90 \mathrm{~g}$ fava beans (Vicia fava), $10 \mathrm{~g}$ lentils (Lens esculenta), $5.2 \mathrm{~g}$ vegetable oil, $3.5 \mathrm{~g}$ calcium hydroxide and $160 \mathrm{ml}$ water. The total Fe content was $5.9 \mathrm{mg}$. The meals were tagged as described previously. Meal $\mathrm{D}$ again consisted of the reference dose.

Study 4 was undertaken to determine whether the low absorption from Egyptian breads observed in the first three studies could be improved by adding EDTA with the fortification Fe. Fe-EDTA is less affected by inhibitory factors than $\mathrm{FeSO}_{4}$ (MacPhail et al. 1981). It was not necessary to prepare Fe-EDTA since all soluble non-haem Fe compounds present in most meals enter a common pool before being absorbed (Bothwell et al. 1979). The percentage absorption of $\mathrm{Fe}$ from the pool is determined by the interaction of enhancing and inhibiting ligands with the whole Fe pool and is independent of the form in which the $\mathrm{Fe}$ enters it. EDTA acts on the common non-haem pool and we have previously demonstrated that the same level of Fe absorption is obtained by adding $\mathrm{Na}_{2}$ EDTA : Fe to a meal in a molar ratio of $1: 1$ as that achieved when radiolabelled Fe-EDTA is used (T. A. Morck, S. R. Lynch and J. D. Cook, unpublished results). Four separate meals were served. The first three consisted of a Baladi bread loaf and $14 \mathrm{~g}$ butter. For meals $\mathrm{A}$ and B, $3.0 \mathrm{mg}$ fortification $\mathrm{Fe}$ as $\mathrm{FeSO}_{4}$ containing $3 \mu \mathrm{Ci}{ }^{55} \mathrm{Fe}$ or $1 \mu \mathrm{Ci}{ }^{59} \mathrm{Fe}$ were added to each $100 \mathrm{~g}$ flour while making the dough. $\mathrm{Na}_{2}$ EDTA $(200 \mathrm{mg} / \mathrm{kg}$ flour $)$ was also added to meal B. For meal C, unfortified flour was used; $2 \cdot 2 \mathrm{mg} \mathrm{Fe}$ as $\mathrm{FeSO}_{4}$ with $1 \mu \mathrm{Ci}$ ${ }^{59} \mathrm{Fe}$ and $14.6 \mathrm{mg} \mathrm{Na} \mathrm{NDDA}_{2}$ were mixed with the butter just before serving the meal. Meal D was the reference dose.

\section{Statistical analysis}

Because of the highly skewed distribution of Fe absorption values when expressed as a percentage of the administered dose, individual values were converted to logarithms for statistical analysis and the results reconverted to anti-logarithms to recover the original units (Cook et al. 1969). All values for $\mathrm{Fe}$ absorption and meal ratios are reported as geometric means. When absorption for any pair of test meals was compared in the same subject, a paired $t$ test was used to determine whether the mean difference in log absorption values differed significantly from 0 . 
Table 1. Iron absorption from unfortified and fortified Baladi bread*

\begin{tabular}{|c|c|c|c|c|c|c|c|c|c|c|}
\hline \multirow{4}{*}{$\begin{array}{c}\text { Subject } \\
\text { no. }\end{array}$} & \multirow[b]{4}{*}{ Sex } & \multirow{4}{*}{$\begin{array}{c}\text { Age } \\
\text { (years) }\end{array}$} & \multirow{4}{*}{$\begin{array}{l}\text { Packed } \\
\text { cell } \\
\text { volume }\end{array}$} & \multirow{4}{*}{$\begin{array}{c}\text { Serum } \\
\text { ferritin } \\
(\mu \mathrm{g} / \mathrm{l})\end{array}$} & \multicolumn{4}{|c|}{$\mathrm{Fe}$ absorption ( $\%$ of dose) } & & \\
\hline & & & & & \multicolumn{2}{|c|}{ Unfortified } & \multicolumn{2}{|c|}{ Fortified } & & \\
\hline & & & & & \multirow{2}{*}{$\begin{array}{c}\text { Intrinsic } \\
\text { label } \\
\text { (A) }\end{array}$} & \multirow{2}{*}{$\begin{array}{c}\text { Extrinsic } \\
\text { label } \\
\text { (B) }\end{array}$} & \multirow{2}{*}{$\begin{array}{l}\text { Before } \\
\text { baking } \\
\text { (C) }\end{array}$} & \multirow{2}{*}{$\begin{array}{c}\text { After } \\
\text { baking } \\
\text { (D) }\end{array}$} & \multicolumn{2}{|c|}{ Absorption ratio } \\
\hline & & & & & & & & & B:A & $C: D$ \\
\hline 1 & 3 & 22 & 0.42 & 96 & 0.96 & $0 \cdot 83$ & $1 \cdot 38$ & 0.93 & $0 \cdot 86$ & $1 \cdot 48$ \\
\hline 2 & 3 & 23 & $0 \cdot 47$ & 61 & 1.02 & 0.76 & 0.26 & $0 \cdot 71$ & 0.74 & $0 \cdot 37$ \\
\hline 3 & $d$ & 22 & 0.46 & 109 & $1 \cdot 61$ & $1 \cdot 30$ & $0 \cdot 76$ & $0 \cdot 70$ & $0 \cdot 80$ & 1.08 \\
\hline 4 & 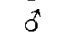 & 22 & $0 \cdot 44$ & 79 & 2.58 & $2 \cdot 61$ & $2 \cdot 85$ & $1 \cdot 81$ & 1.01 & $1 \cdot 57$ \\
\hline 5 & 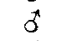 & 22 & 0.46 & 101 & $2 \cdot 68$ & $2 \cdot 57$ & $1 \cdot 75$ & 0.81 & 0.95 & $0 \cdot 31$ \\
\hline 6 & $\delta$ & 23 & $0 \cdot 50$ & 43 & $2 \cdot 81$ & $3 \cdot 22$ & 3.61 & $1 \cdot 73$ & $1 \cdot 14$ & 2.09 \\
\hline 7 & $\sigma^{x}$ & 24 & 0.46 & 81 & 3.07 & $2 \cdot 70$ & $1 \cdot 40$ & 1.32 & 0.87 & 1.06 \\
\hline 8 & $\delta^{*}$ & 19 & 0.44 & 107 & 7.66 & 8.03 & $10 \cdot 22$ & 5.97 & 0.48 & $1 \cdot 71$ \\
\hline Mean $\dagger$ & - & 22 & 0.46 & 81 & $2 \cdot 28$ & $2 \cdot 10$ & 1.70 & 1.32 & 0.92 & 1.29 \\
\hline$-2 \mathrm{SE}$ & - & - & - & - & 1.42 & $1 \cdot 21$ & 0.79 & 0.80 & 0.84 & 0.52 \\
\hline$+2 \mathrm{SE}$ & - & - & - & - & 3.66 & $3 \cdot 65$ & $3 \cdot 67$ & $2 \cdot 19$ & 1.02 & $1 \cdot 16$ \\
\hline
\end{tabular}

Table 2. Iron absorption from different fortified breads*

\begin{tabular}{|c|c|c|c|c|c|c|c|c|c|c|c|}
\hline \multirow{3}{*}{$\begin{array}{c}\text { Subject } \\
\text { no. }\end{array}$} & \multirow{3}{*}{ Sex } & \multirow{3}{*}{$\begin{array}{c}\text { Age } \\
\text { (years) }\end{array}$} & \multirow{3}{*}{$\begin{array}{c}\text { Packed } \\
\text { cell } \\
\text { volume }\end{array}$} & \multirow{3}{*}{$\begin{array}{c}\text { Serum } \\
\text { ferritin } \\
(\mu \mathrm{g} / 1)\end{array}$} & \multicolumn{4}{|c|}{$\mathrm{Fe}$ absorption ( $\%$ of dose) } & \multirow{2}{*}{\multicolumn{3}{|c|}{ Absorption ratio }} \\
\hline & & & & & \multirow{2}{*}{$\begin{array}{c}\text { French } \\
\text { bread } \\
\text { (A) }\end{array}$} & \multirow{2}{*}{$\begin{array}{c}\text { Shami } \\
\text { bread } \\
\text { (B) }\end{array}$} & \multirow{2}{*}{$\begin{array}{c}\text { Baladi } \\
\text { bread } \\
\text { (C) }\end{array}$} & \multirow{2}{*}{$\begin{array}{l}\text { Reference } \\
\text { (D) }\end{array}$} & & & \\
\hline & & & & & & & & & B:A & $C: B$ & $\mathrm{C}: \mathrm{A}$ \\
\hline 1 & 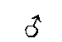 & 23 & 0.47 & 177 & $2 \cdot 07$ & $2 \cdot 31$ & 1.08 & $11 \cdot 68$ & $1 \cdot 11$ & 0.46 & 0.52 \\
\hline 2 & o & 20 & 0.50 & 29 & 3.82 & 7.68 & $1 \cdot 80$ & $40 \cdot 23$ & 2.01 & 0.23 & 0.47 \\
\hline 3 & $\hat{0}$ & 20 & 0.51 & 97 & $5 \cdot 60$ & $2 \cdot 76$ & 0.67 & $23 \cdot 11$ & 0.49 & 0.24 & $0 \cdot 11$ \\
\hline 4 & 9 & 22 & $0 \cdot 40$ & 19 & 13.76 & $3 \cdot 76$ & $1 \cdot 17$ & $33 \cdot 17$ & $0 \cdot 27$ & 0.31 & 0.08 \\
\hline 5 & $\stackrel{+}{q}$ & 29 & 0.47 & 16 & $24 \cdot 22$ & $8 \cdot 60$ & $1 \cdot 10$ & 64.73 & 0.35 & $0 \cdot 12$ & $0 \cdot 04$ \\
\hline 6 & q & 23 & 0.45 & 9 & $38 \cdot 32$ & 27.88 & 7.67 & 56.03 & 0.72 & 0.27 & 0.20 \\
\hline 7 & $\stackrel{+}{+}_{+}^{+}$ & 26 & 0.38 & 11 & 43.47 & $33 \cdot 31$ & 6.02 & 67.27 & 0.76 & 0.18 & 0.13 \\
\hline 8 & $q$ & 23 & 0.44 & 9 & $44 \cdot 88$ & $20 \cdot 40$ & $6 \cdot 46$ & $91 \cdot 47$ & 0.45 & 0.31 & 0.14 \\
\hline Meant & & 23 & 0.45 & 25 & $13 \cdot 50$ & $8 \cdot 60$ & $2 \cdot 17$ & $41 \cdot 03$ & 0.64 & 0.25 & $0 \cdot 16$ \\
\hline$-2 \mathrm{SE}$ & & - & $\ldots$ & - & $5 \cdot 77$ & $4 \cdot 10$ & $1 \cdot 10$ & $25 \cdot 54$ & 0.40 & 0.19 & 0.09 \\
\hline$+2 \mathrm{SE}$ & & - & $\ldots$ & - & $31 \cdot 60$ & $18 \cdot 04$ & $4 \cdot 31$ & 65.92 & 1.01 & 0.33 & 0.29 \\
\hline
\end{tabular}

* For details, see pp. 206-207.

$\dagger$ Geometric mean except for age and packed cell volume.

\section{RESULTS}

Labelling technique (study 1). There was no appreciable difference in absorption of the intrinsic and extrinsic radio-Fe tags from Baladi bread (Table 1). Mean absorption was $2 \cdot 3 \%$ from the intrinsic label and $2 \cdot 1 \%$ from the extrinsic tag, giving a mean absorption ratio of 0.92 (not significantly different from $1.00 ; t 1.45, P=0.18$ ). In the second pair of test meals, absorption of $\mathrm{Fe}$ added to the dough was slightly higher than that of $\mathrm{Fe}$ added to the bread after it had been baked $(1 \cdot 7$ v. $1 \cdot 3 \%$, meals $\mathrm{C}$ and $\mathrm{D}$ respectively), but the 
Table 3. Iron absorption from fortified Baladi bread consumed with typical Egyptian meals*

\begin{tabular}{|c|c|c|c|c|c|c|c|c|c|c|c|}
\hline \multirow{4}{*}{$\begin{array}{c}\text { Subject } \\
\text { no. }\end{array}$} & \multirow{4}{*}{\multicolumn{2}{|c|}{$\begin{array}{c}\text { Age } \\
\text { Sex (years) }\end{array}$}} & \multicolumn{6}{|c|}{ Fe absorption ( $\%$ of dose) } & & & \\
\hline & & & \multirow{3}{*}{$\begin{array}{c}\text { Packed } \\
\text { cell } \\
\text { volume }\end{array}$} & \multirow{3}{*}{$\begin{array}{l}\text { Serum } \\
\text { ferritin } \\
(\mu \mathrm{g} / 1)\end{array}$} & \multicolumn{3}{|c|}{ Baladi bread } & \multirow{3}{*}{$\begin{array}{l}\text { Reference } \\
\text { (D) }\end{array}$} & \multirow{2}{*}{\multicolumn{3}{|c|}{ Absorption ratio }} \\
\hline & & & & & \multirow{2}{*}{$\begin{array}{l}\text { Rice and } \\
\text { vegetables } \\
+ \text { water } \\
\text { (A) }\end{array}$} & \multirow{2}{*}{$\begin{array}{l}\text { Rice and } \\
\text { vegetables } \\
\text { + tea } \\
\text { (B) }\end{array}$} & \multirow{2}{*}{$\begin{array}{c}\text { Fava } \\
\text { beans } \dagger \\
\text { (C) }\end{array}$} & & & & \\
\hline & & & & & & & & & $A: D$ & $B: D$ & $\mathrm{C}: \mathrm{D}$ \\
\hline 1 & q & 24 & 0.42 & 54 & 0.33 & 0.07 & 0.45 & $9 \cdot 26$ & 0.03 & 0.01 & 0.04 \\
\hline 2 & $\hat{0}$ & 23 & 0.46 & 167 & 0.62 & $0 \cdot 20$ & 0.35 & $11 \cdot 00$ & 0.05 & 0.01 & 0.03 \\
\hline 3 & 3 & 27 & 0.51 & 74 & 0.63 & 0.05 & 0.46 & $16 \cdot 11$ & 0.03 & 0.01 & 0.02 \\
\hline 4 & 0 & 31 & 0.47 & 63 & $2 \cdot 12$ & 0.47 & $0 \cdot 76$ & $18 \cdot 03$ & $0 \cdot 1 \mathrm{I}$ & 0.02 & 0.04 \\
\hline 5 & $q$ & 22 & 0.43 & 19 & $2 \cdot 27$ & 1.60 & $2 \cdot 72$ & $41 \cdot 33$ & 0.05 & $0 \cdot 03$ & 0.06 \\
\hline 6 & 웅 & 34 & 0.44 & 17 & $2 \cdot 81$ & $1 \cdot 37$ & $13 \cdot 36$ & $49 \cdot 98$ & $0-05$ & $0 \cdot 03$ & 0.06 \\
\hline 7 & $q$ & 23 & 0.40 & 48 & $4 \cdot 65$ & $2 \cdot 67$ & $1 \cdot 68$ & $18 \cdot 03$ & $0 \cdot 25$ & $0 \cdot 14$ & 0.09 \\
\hline 8 & $q$ & 22 & 0.43 & 8 & $4 \cdot 68$ & 1.86 & $2 \cdot 91$ & $20 \cdot 61$ & 0.22 & 0.09 & $0 \cdot 14$ \\
\hline 9 & $q$ & 34 & 0.41 & 7 & 18.47 & $8 \cdot 15$ & $19 \cdot 82$ & $85 \cdot 21$ & $0 \cdot 21$ & 0.09 & 0.23 \\
\hline Mean $\ddagger$ & & 27 & 0.44 & 32 & $2 \cdot 07$ & 0.68 & 1.80 & $23 \cdot 18$ & 0.09 & 0.03 & 0.08 \\
\hline$-2 \mathrm{SE}$ & & - & - & - & 0.90 & 0.21 & 0.67 & $14 \cdot 23$ & 0.06 & 0.02 & 0.04 \\
\hline$+2 \mathrm{SE}$ & & - & - & 一 & $4 \cdot 76$ & $2 \cdot 14$ & $4 \cdot 80$ & $37 \cdot 77$ & $0 \cdot 20$ & 0.07 & 0.13 \\
\hline
\end{tabular}

Table 4. Iron absorption from Baladi bread fortified with ferrous sulphate or Fe-EDTA*

\begin{tabular}{|c|c|c|c|c|c|c|c|c|c|c|c|}
\hline \multirow{5}{*}{$\begin{array}{c}\text { Subject } \\
\text { no. }\end{array}$} & \multirow{5}{*}{\multicolumn{2}{|c|}{$\begin{array}{c}\text { Age } \\
\text { Sex (years) }\end{array}$}} & \multicolumn{6}{|c|}{ Fe absorption ( $\%$ of dose) } & & & \\
\hline & & & \multirow{4}{*}{$\begin{array}{c}\text { Packed } \\
\text { cell } \\
\text { volume }\end{array}$} & \multirow{4}{*}{$\begin{array}{l}\text { Serum } \\
\text { ferritin } \\
(\mu \mathrm{g} / 1)\end{array}$} & \multicolumn{3}{|c|}{ Baladi bread } & \multirow{4}{*}{$\begin{array}{l}\text { Reference } \\
\text { (D) }\end{array}$} & & & \\
\hline & & & & & \multirow{3}{*}{$\begin{array}{c}\mathrm{FeSO}_{4} \\
\text { (A) }\end{array}$} & \multicolumn{2}{|c|}{ Fe-EDTA } & & & & \\
\hline & & & & & & Before & After & & \multicolumn{3}{|c|}{ Absorption ratio } \\
\hline & & & & & & (B) & (C) & & B : A & $\mathrm{C}: \mathrm{A}$ & $\mathrm{B}: \mathrm{C}$ \\
\hline 1 & $q$ & 28 & 0.43 & 72 & 0.41 & $1 \cdot 37$ & 1.52 & $13 \cdot 52$ & $3 \cdot 34$ & $3 \cdot 70$ & 0.09 \\
\hline 2 & $\hat{0}$ & 29 & 0.43 & 133 & 0.45 & 1.63 & 1.55 & $17 \cdot 68$ & $3 \cdot 62$ & 3.44 & 1.05 \\
\hline 3 & $q$ & 27 & $0 \cdot 39$ & 58 & $0 \cdot 75$ & $2 \cdot 03$ & $2 \cdot 11$ & $17 \cdot 43$ & $2 \cdot 70$ & $2 \cdot 81$ & 0.96 \\
\hline 4 & q & 35 & 0.36 & 37 & 1.03 & $3 \cdot 10$ & $3 \cdot 36$ & $40 \cdot 74$ & 3.00 & $3 \cdot 26$ & 0.92 \\
\hline 5 & 9 & 26 & 0.41 & 16 & 1.51 & $8 \cdot 38$ & $11-21$ & $64 \cdot 28$ & $5 \cdot 54$ & $7 \cdot 42$ & 0.74 \\
\hline 6 & $q$ & 25 & 0.40 & 26 & 1.62 & $3 \cdot 41$ & $13 \cdot 51$ & 8.90 & $2 \cdot 10$ & $2 \cdot 16$ & 0.97 \\
\hline 7 & 9 & 24 & $0 \cdot 38$ & 8 & $2 \cdot 05$ & $13 \cdot 41$ & $27 \cdot 17$ & $106 \cdot 47$ & 6.54 & $13 \cdot 25$ & 0.49 \\
\hline 8 & q & 23 & 0.43 & 44 & 2.63 & 3.41 & $5 \cdot 43$ & $31 \cdot 06$ & $1 \cdot 29$ & $2 \cdot 06$ & 0.62 \\
\hline 9 & q & 30 & 0.43 & 33 & $3 \cdot 18$ & 4.03 & 14.61 & $62 \cdot 48$ & $1 \cdot 26$ & $4 \cdot 59$ & 0.27 \\
\hline 10 & 9 & 20 & 0.42 & 15 & $4 \cdot 30$ & 6.22 & 8.81 & $26 \cdot 27$ & 1.44 & $2 \cdot 04$ & 0.70 \\
\hline 11 & $q$ & 21 & $0 \cdot 42$ & 31 & $6 \cdot 26$ & 11.82 & $9 \cdot 37$ & $45 \cdot 38$ & 1.88 & $1 \cdot 49$ & 1.26 \\
\hline Meant & & 26 & 0.41 & 32 & 1.59 & $4 \cdot 10$ & 5.41 & $30 \cdot 83$ & $2 \cdot 58$ & $3 \cdot 41$ & 0.76 \\
\hline$-2 \mathrm{SE}$ & & - & - & - & 0.93 & $2 \cdot 58$ & 3.04 & $19 \cdot 57$ & 1.84 & $2 \cdot 33$ & 0.59 \\
\hline$+2 \mathrm{sE}$ & & - & - & - & $2 \cdot 71$ & 6.51 & 9.63 & 47.58 & 3.61 & 4.99 & 0.98 \\
\hline
\end{tabular}

* For details, see pp. 206-207.

+ Geometric mean except for age and packed cell volume. 


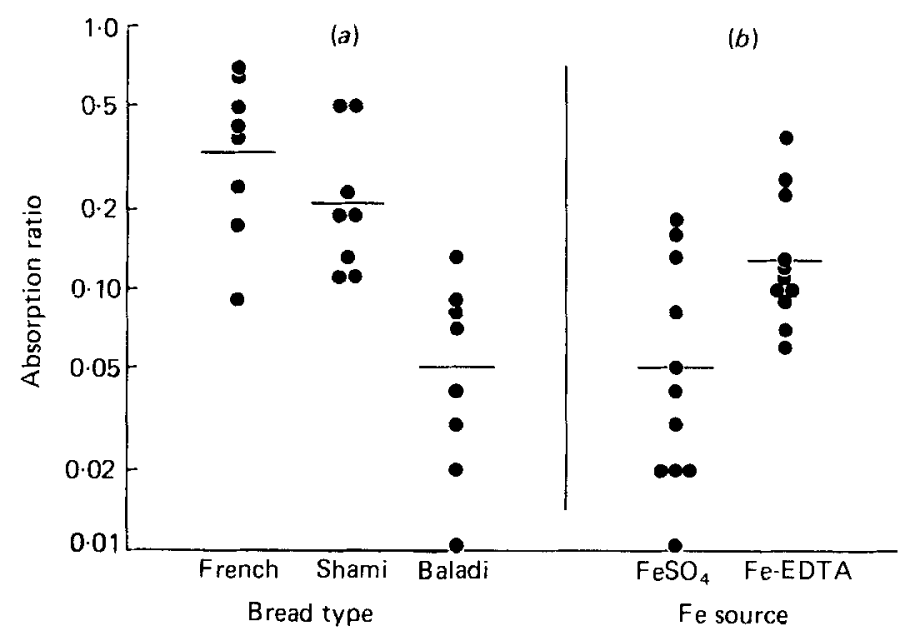

Fig. 1. Effect of type of bread and fortification iron on Fe absorption, expressed as a ratio with respect to reference dose absorption. (a) Fortified with ferrous sulphate for all meals; (b) Baladi bread was used for both studies. The horizontal bars represent the geometric mean values. Note that by expressing absorption relative to the reference dose, an identical absorption ratio was obtained for Baladi bread fortified with $\mathrm{FeSO}_{4}$ in the two studies.

difference was not statistically significant $(t 1 \cdot 17, P=0 \cdot 28)$. It should be noted that by increasing the Fe content of the bread from $1.8 \mathrm{mg}$ (meal B) to $4.0 \mathrm{mg}$ (meal D), there was a modest decrease in percentage absorption, although this difference was not significant $(t 1.06, P=0.32)$.

Comparison of bread products (study 2). The availability of Fe from the three bread products was quite different (Table 2). Absorption from French bread (meal A) was high, averaging $13.5 \%$. It fell to $8.6 \%$ when the same dough was baked at a higher temperature (Shami bread, meal B), although the difference was not statistically significant $(t 1.84$, $P=0 \cdot 10$ ). However, when $82 \%$-extraction flour was used (Baladi bread) absorption decreased dramatically to $2.2 \%$ (meal $\mathrm{C}$ ). This reduction was significant when compared with both Shami bread (mean ratio $0.25, t 9.34, P<0.001$ ) and with French bread (mean ratio $0 \cdot 16, t 5 \cdot 89, P<0 \cdot 001)$.

Effect of Egyptian meals (study 3). Absorption from fortified Baladi bread consumed with typical Egyptian meals was similar to that from the bread eaten alone. Mean absorption from the dinner meal (A) was $2.1 \%$ (Table 3), giving a mean absorption ratio relative to the reference dose of 0.09 , which is close to the value of 0.05 observed with Baladi bread in study 2 . Similarly, absorption from the breakfast meal $(\mathrm{C})$ averaged $1.8 \%$, giving a ratio relative to the reference dose of 0.08 . Absorption fell significantly from $2.1 \%$ (A) to $0.68 \%$ $(t 4.77, P=0.001$ ) when tea was consumed with the dinner meal (B).

Form of fortification $\mathrm{Fe}$ (study 4). A substantial improvement in availability was demonstrated when EDTA was added to Baladi bread (Table 4). When the Fe was added to the dough before baking, absorption from bread containing EDTA averaged $4.1 \%$ compared with $1.6 \%$ from $\mathrm{Fe}_{2} \mathrm{SO}_{4}$ alone. This 2.5 -fold increase in absorption was highly significant $(t 5 \cdot 37, P<0.001)$. Even better absorption, $5 \cdot 4 \%$, was obtained when the Fe and EDTA were added to the bread after it was baked (C), although the difference ( $\mathrm{C} v \mathrm{~B})$ was not significant $(t 2 \cdot 07, P=0 \cdot 06)$.

A more reliable comparison of Fe-absorption in these studies is obtained by calculating the ratio, absorption from bread:reference dose absorption (Fig. 1). The absorption ratio for Baladi bread averaged 0.05 compared with 0.33 and 0.21 observed with French and 
Shami breads respectively. The addition of EDTA to the fortification Fe increased the absorption ratio from 0.05 to $0 \cdot 13$. The composite mean reference absorption was $30.5 \%$. Since $40 \%$ reference-dose absorption is commonly assumed to represent Fe-deficiency (Hallberg, 1980), absorption values would be $30 \%$ higher in Fe-deficient individuals.

\section{DISCUSSION}

A reduction in the high prevalence of Fe deficiency in the developing world will require the provision of additional Fe, either by Fe supplementation or fortification. Supplemental or medicinal $\mathrm{Fe}$ has been used as a short-term approach during pregnancy and occasionally in school-age children. However, the efficacy of $\mathrm{Fe}$ supplementation has been questioned in recent years. The regular distribution of Fe tablets requires sophisticated health delivery systems which are often lacking in Third World countries. In addition, compliance is often a major obstacle to this approach because of the gastrointestinal side effects associated with medicinal Fe. The most effective strategy for reducing the prevalence of Fe-deficiency is dietary $\mathrm{Fe}$ fortification.

There are a number of constraints to developing an effective programme of $\mathrm{Fe}$ fortification at a national level (Cook \& Reusser, 1983). The most critical is the availability of a suitable food vehicle. The food must reach a high proportion of the population, have no potential for idiosyncratic intake, and be equally available to people of differing socioeconomic status. Further, it must be inexpensive, centrally processed to permit government regulation, and support relatively high absorption of the added Fe. In Egypt wheat flour meets these requirements. It is heavily subsidized within the country and reaches virtually all segments of the population. Wheat consumption averages $180 \mathrm{~kg} /$ person per year and provides nearly $50 \%$ of the average daily intake of both energy and protein. Half the population eats Baladi bread, at an average consumption of three $169 \mathrm{~g}$ loaves daily. Shami and French breads are also popular, with consumption levels averaging five $125 \mathrm{~g}$ loaves/d. Wheat flour is clearly an excellent vehicle for food Fe fortification in Egypt.

Although previous studies in human beings have demonstrated relatively high absorption when available forms of $\mathrm{Fe}$ are added to wheat products (International Nutritional Anemia Consultative Group, 1982), there are reasons to suspect that availability may be substantially less with Egyptian flat breads. Baladi bread is prepared from high-extraction flour, and has a high content of bran which is known to inhibit Fe absorption (BjornRasmussen, 1974). Also, the high baking temperatures used for Egyptian flat breads may render added $\mathrm{Fe}$ less available for absorption. In the present studies, the absorption from Shami bread was only about $65 \%$ that observed from French bread, but the difference was not statistically significant. However, a dramatic fourfold reduction was observed with Baladi bread, almost certainly due to its higher content of bran. The effect of higher baking temperature was marginal.

A major constraint to implementing Fe-fortification programmes in developing countries is the nature of the diet. Although availability from a fortified food eaten alone may be high, absorption is affected by other common pool ligands when the food is part of a meal. Most diets in developing countries are characterized by a low content of substances that promote $\mathrm{Fe}$ absorption, such as meat and ascorbic acid, and a high content of vegetable and cereal foods. The present study demonstrates that $\mathrm{Fe}$ absorption from fortified Baladi bread is no lower when eaten with food than when eaten alone, except when the meal includes tea which produces a threefold reduction in absorption. Tea, the most potent inhibitor of nonhaem-Fe absorption yet identified (Disler et al. 1975; Rossander et al. 1979), is widely consumed in Egypt and this may be a far greater impediment to an effective fortification programme than the inhibiting effect of high-extraction flour. Bread is eaten both alone and 
with meals, but tea is almost always part of the meal. We did not examine the effect of a meal on Fe-absorption from Shami or French breads, but it is likely that an inhibitory meal would mask the observed differences in $\mathrm{Fe}$ absorption from the various breads.

One approach to reducing the inhibiting effect of a cereal- or vegetable-based diet on $\mathrm{Fe}$ absorption is to include an enhancing substance such as ascorbic acid with the fortification Fe (International Nutritional Anemia Consultative Group, 1982). Unfortunately, ascorbic acid is unstable and is ineffective in bread because oxidation occurs during baking (Sayers et al. 1974). EDTA is more stable and has similar enhancing properties. NaFe-EDTA (molar ratio, EDTA:Fe of $1: 1$ ) may be absorbed adequately even from strongly inhibitory meals (Garby \& Areekul, 1974; Layrisse \& Martinez-Torres, 1977; Viteri et al. 1978; MacPhail et al. 1981). However, unlike ascorbic acid, an increasing molar ratio of EDTA : Fe leads to reduced Fe absorption (Cook \& Monsen, 1976). The use of a fortifier consisting of EDTA and Fe is therefore potentially valuable, especially in diets that do not already contain appreciable quantities of EDTA. NaFe-EDTA has been used to fortify a variety of vehicles including fish sauce in Thailand (Garby \& Areekul, 1974), sugar in Guatemala (Viteri et al. 1978), and the seasoning, masala, in South Africa (MacPhail et al. 1981). The findings in the present report suggest the addition of Fe together with EDTA should also be considered in Egypt. Fe absorption from meals containing EDTA was nearly three times greater than that from those with $\mathrm{FeSO}_{4}$ alone. Although EDTA is unstable at high temperatures, only minimal reduction in absorption occurred when it was added to Baladi bread before baking. Presumably exposure to these temperatures was too brief to have a major deleterious effect. The use of Fe-EDTA could offset the strongly inhibitory effects of the typical Egyptian diet.

The present work was supported by AID Cooperative Agreement DAN-0227-A-00-210400 .

\section{REFERENCES}

Bjorn-Rasmussen, E. (1974). Nutritional Metabolism 16, 101-110.

Bjorn-Rasmussen, E. \& Hallberg, L. (1974). Nutritional Metabolism 16, 94-100.

Bothwell, T. H., Charlton, R. W., Cook, J. D. \& Finch, C. A. (1979). Iron Metabolism in Man, 1st edn, pp. 401-410. Oxford: Blackwell Scientific.

Brown, E., Hooper, J., Hodges, J. L., Bradley, B., Wennesland R. \& Yamaushi, M. (1962). Journal of Clinical Investigation 41, 2182-2190.

Cook, J. D., Layrisse, M. \& Finch, C. A. (1969). Blood 33, 42I-429.

Cook, J. D., Layrisse, M., Martinez-Torres, C., Walker, R., Monsen, E. \& Finch, C. A. (1972). Journal of Clinical Investigation 51, 805-815.

Cook, J. D. \& Monsen, E. R. (1976). American Journal of Clinical Nutrition 29, 614-620.

Cook, J. D. \& Reusser, M. E. (1983). American Journal of Clinical Nutrition 38, 648-659.

Cook, J. D., Skikne, B. S., Lynch, S. R. \& Reusser, M. E. (1986). Blood 68, 726-731.

Disler, P. B., Lynch, S. R., Charlton, R. W., Torrance, J. D. \& Bothwell, T. H. (1975). Gut 16, 193-200.

Garby, L. \& Areekul, S. (1974). Annals of Tropical Medicine and Parasitology 68, 467-476.

Hallberg, L. (1980). In Methods in Hematology: Iron, pp. 116-133 [J. D. Cook, editor]. New York: Churchill Livingstone.

Hallberg, L., Bengtason, C., Garby, L., Lennartsson, J., Rossander, L. \& Tibblin, E. (1979). Bulletin WHO 57, $947-954$.

Hallberg, L., Bjorn-Rasmussen, E., Rossander, L. \& Suwanik, R. (1977). American Journal of Clinical Nutrition 30, 539-548.

Hosain, F., Marsaglia, G. \& Finch, C. A. (1967). Journal of Clinical Investigation 46, $1-9$.

International Nutritional Anemia Consultative Group (1982). Report of the International Nutritional Anemia Consultative Group (INACG). Washington DC and New York: The Nutrition Foundation.

Layrisse, M. \& Martinez-Torres, C. (1977). American Journal of Clinical Nutrition 30, 1166-1174.

MacPhail, A. P., Bothwell, T. H., Torrance, J. D., Derman, D. P., Bezwoda, W. R., Charlton, R. W. \& Mayet, F. (1981). British Journal of Nutrition 45, 215-227.

Miles, L. E. M., Lipschitz, D. A., Bieber, C. P. \& Cook, J. D. (1974). Analytical Biochemistry 61, $209-224$.

Moore, C. V. \& Dubach, R. (1951). Transactions of the Association of American Physicians 64, 245-256.

Rossander, L., Hallberg, L. \& Bjorn-Rasmussen, E. (1979). American Journal of Clinical Nutrition 32, $2482-2489$. 
Sayers, M. H., Lynch, S. R., Charlton, R. W., Bothwell, T. H., Walker, R. B. \& Mayet, F. (1974). British Journal of Nutrition 31, 367-375.

Simpson, K. M., Morris, E. R. \& Cook, J. D. (1981). American Journal of Clinical Nutrition 34, 1469-1478.

Viteri, F. E., Garcia-Ibanez, R. \& Torun, B. (1978). American Journal of Clinical Nutrition 31, 961-971.

Wennesland, R., Brown, E., Hopper, J., Hodges, L., Guttentag, O. E., Scott, K. G., Tucker, I. N. \& Bradley, B. (1959). Journal of Clinical Investigation 38, 1065-1077.

Widdowson, E. M. \& McCance, R. A. (1942). Lancet i, 588-591. 